\title{
Hezbollah, Islamic State of Iraq And Syria And Foreign Interests in The Middle East
}

\author{
Dr Adewumi, Eyitayo F \\ Department of Political Science \& Public Administration, Babcock University \\ Eze-Michael, Ezedikachi N \\ Department of Political Science \& Public Administration, Babcock University, \\ Professor Oni, Michael Abiodun \\ Department of Political Science \& Public Adminstration, Babcock University
}

\begin{abstract}
The focal points of foreign interests within the Middle East are crude oil resources, prevention of nuclear proliferation, the fight against terrorism, and promoting democratization. International actors have specific interests they seek in the region. Among these, the US interests are the protection and free flow of oil, and the control of nuclear weapons to prevent threats against the security of crude oil, Russia's interests are arms sales, energy and investment while China's interest is to have a continued access to energy resources. The scramble for these interests among these international actors brought about the crisis that weakened the security of the states in the Middle East. The weak security caused many ethnic and religious nationalities to begin engaging in conflicts which eventually escalated into civil war. This war led to confrontations between regional states thus, providing Hezbollah and the Islamic State of Iraq and Syria (ISIS) the opportunity to rise up to fill the security vacuum in the region. The study therefore investigated the roles and consequences of Hezbollah and ISIS on foreign interests in the Middle East.
\end{abstract}

The study adopted qualitative method. The population of the study was the violent organizations in the Middle East. Hezbollah and ISIS were purposively selected because they constituted the major security threats in an already volatile region between 2010 and 2017. Data were collected through documentary review (of publications and audiovisual recordings by Hezbollah and ISIS as well as journals and materials from Internet). Data from interviews of five Syrians and four American citizens complemented the major sources. Data were analyzed thematically.

The study found that the interference in the Middle East crisis by foreign interests led to the rise of violent groups in the region. In addition, the support of some groups by Russia, China, Japan and USA on the pretext of humanitarian intervention fuelled the Hezbollah and ISIS violent activities. ISIS denied Russia access to their oil pipeline route and that affected Russia's federal fund and foreign earnings, causing a decimation of profits for the Russian government. Furthermore, the trade route owned and managed by the Chinese construction company was destroyed by Hezbollah. This made China to lose trade route access from the Middle East to the rest of the world. In addition, the US military base in Syria was attacked by the ISIS and it resulted into casualties of some Americans.

The study concluded that the foreign economic and military interests in the Middle East had been decimated by Hezbollah and ISIS. The study recommended that the various governments of the Middle East in dealing with the foreign interests should take cognizance of the internal demands of their citizens.

Keywords: Foreign interests, Hezbollah, ISIS, Middle East

DOI: $10.7176 / \mathrm{IAGS} / 73-04$

Publication date:June $30^{\text {th }} 2019$

\section{Introduction}

The focal points of foreign interests within the Middle East are crude oil resources, prevention of nuclear proliferation, the fight against terrorism, and promoting democratization. International actors have specific interests they seek in the region. Among these, the US interests are the protection and free flow of oil, and the control of nuclear weapons to prevent threats against the security of crude oil, Russia's interests are arms sales, energy and investment while China's interest is to have a continued access to energy resources. The scramble for these interests among these international actors brought about the crisis that weakened the security of the states in the Middle East. The weak security caused many ethnic and religious nationalities to begin engaging in conflicts which eventually escalated into civil war. This war led to confrontations between regional states thus, providing Hezbollah and the Islamic State of Iraq and Syria (ISIS) the opportunity to rise up to fill the security vacuum in 
the region. The study therefore investigated the roles and consequences of Hezbollah and ISIS on foreign interests in the Middle East between 2010 and 2017.

\section{Concept of Non-State Actors}

The term non-state actor according to Haynes (2014) can be applied to non-governmental groups who directly or indirectly engage in support of non-governmental combatants and are sometimes combatants themselves. These groups can engage in non-international and purely internal conflicts, they can also get themselves involved in international conflict such as that of international terrorist organizations have been known to be involved in (Bush, 2016). Non-state actors have been variously defined. According to Meier (2015) non-state actors include organizations that are largely or entirely autonomous from central government funding and control. The actions of these organizations usually affect political outcomes, either within one or more states or within international institutions, either purposefully or semi purposefully, either as their primary objective or as one aspect of their activities (Meier, 2015). Non-state actors range from Multinational Corporations, Nongovernmental Organizations, Intergovernmental Organizations, religious groups, individuals and Violent Non-state actors (National Intelligence Council). However the types of non-state actors that will be discussed in this study are the violent ones.

\subsection{Accretion of Non-State Actors}

The international arena evolves and new non-state actors arise. Seyom Brown labels it 'polyarchic, which means a highly interactive and interdependent, yet decentralized, system of many kinds of actors, large and small, state and non-state' (Brown, 2016 p.244). Furthermore, Brown observes a relative rise in power of the non-state actors, which can be in coalitions with state actors in a dynamic system of highly unpredictable relationships (Brown, 2016). In his analysis, he used Hedley Bull's concept of New Medievalism and emphasizes that apart from the nation states, thousands of non-state actors also have the capacity to fight as well (Brown, 2016). A similar tendency was observed by Aydinli (2013), who describes a transfer of power from states, to non-states and went further to explain how the state is losing its predominance within world politics (Aydinli, 2013). Moisés Naím observes a decrease of power among traditional actors in numerous fields, including international politics. Instead micro-powers are rising, 'small, unknown, and once negligible actors who are now finding their ways to undermine, fence in, and thwart the mega players, the large bureaucratic organizations that have previously controlled their fields' (Naím, 2014 p.51). The reasons were classified into three developments which was labeled by Naím as the 'more,' 'mobility,' and 'mentality' revolutions. The 'more' revolution concerns the increasing population, whom on average live better lives and have higher education than previous generations, which makes these category of people more difficult to be kept in check. This, according to Naím, is further increased by the improved availability of transportation and communication compared to the then mobility revolution. The 'more' and 'mobility' developments contributed in establishing huge middle classes in societies all over the world. Within these middle classes, expectations of people increased, and this made the authorities to be incapable of providing most of their needs, thus creating political turmoil (Naím, 2014).

The fragmentation of power gradually extended into international politics. Even though, not officially recognized, non-state entities began to carry out 'de facto foreign policy.' (Naím, 2014 p.97) Although it is impossible to exactly quantify the influence that non-state actors exert in world politics, scholarly attention and academic works indicate that non-state actors have become more important at the expense of state actors. It is not out of point therefore, to say that some non-state actors can and do challenge the states' authority.

\subsection{Invasion of Violence into Non-State Actors Activities}

There are several reasons which have been given for the invasion of violence into activities of some non-state actors. According to Poole (2004), one of such reasons was that many Muslim nations have a growing number of youths who have taken upon themselves the responsibility of ensuring that foreign invaders are expelled from Islamic countries. Again, Benson and Kugler (2016) used a measure called Relative Political Extraction (RPE) to show that insurgencies produce violence within a country where there is some level of parity within a government. The problem of high level of poverty as Fearon and Laitin (2002) posit, also brought into limelight why non-state actors use violence in their approach. Disenfranchised citizens who have suffered in abject poverty felt that the only way they could react against some of their government policies and decisions was to become insurgents.

\subsection{Violent Actors and Preponderance of Foreign Interest in the Middle East}

The emergence of violent non-state actors in Middle East did not arise as an isolated event but was influenced by global occurrences in the region. Blumenau (2014) opines that, the rivalry that existed between the United States of America and the Soviet Union during the Cold War played a historical role in the emergence of violent groups like al-Qaeda. The Soviet Union's desire to control most countries in Eastern Europe and the Middle East was 
behind its invasion of Afghanistan in the 1980s, following its successful control of countries like Kazakhstan and others in the region (Blumenau, 2014). However, its entry into Afghanistan was met by heavy resistance by Arab forces under the leadership of Osama bin Laden. Interestingly, the U.S. and Pakistan supported and equipped the group as part of a foreign campaign against the Soviet Union. As the revolt against the Soviet Union continued, the U.S. engaged al-Qaeda in other missions (Demollari, 2015). In the 1990s, the group was allowed to be part of the Caucasus that fought the Soviet Union invasions of the Middle East. The group was also allowed in the military activities of the Americans and other Western countries in Kosovo against the Serbs. Due to the situation that faced the region, al-Qaeda was formed solely as a Pan-Arab group with the mandate of protecting the Arabian Peninsula. Under the leadership of bin Laden, the group transformed into a terrorist group, and turned its guns against its former allies (Burc, 2014). The group has targeted some countries in the West in order to discourage them from also supporting Israel (Burc, 2014).

As al-Qaeda militias continued with their resistance against the Soviet Union invasion of Afghanistan, other groups emerged with support for Pakistan. During the same period, the Pakistani intelligence service was involved in the training of Pashtun jihadist groups to reduce the influence of India in the region. Pakistan and Indian rivalry, in essence, played a supportive role in increasing the presence of these groups in the Middle East. The Pashtun jihadists were also sent to Afghanistan to help al-Qaeda in fighting the Soviet Union invasion of the region. Coincidentally, Pakistan was an ally of the U.S. during this time, an indication that they have also contributed to the creation of the Taliban. Al-Qaeda, initially sponsored by the U.S., turned its weapons against the U.S. and their support. In Pakistan, the Taliban set up hard-line Islamic schools in which studies were devoted to their terrorist beliefs and from which they recruited Pakistani jihadists to fight their wars. Because of these schools, the word Taliban came to mean "student" (Burc, 2014). Today, the group waged war against the Pakistani people because of their international policies and alliance with Western powers. Again, the creation of Israel by the United Nations after the Second World War contributed to the emergence of terrorist groups in the Middle East in the name of "jihad." By carving out a place for Israel close to Arab-dominated regions, the world created a rivalry that has persisted beyond the original cause. Israel was and has always been supported by Western countries such as the United States of America, Russia, and China. The formation of the North Atlantic Treaty Organization (NATO), a military alliance supported by the U.S. and most European countries further complicated the rivalry.

Most Arab countries had no financial base to counter Israel or fight its allies; this led to the formation of violent actors fighting against the creation of the Israeli state and the Middle Eastern regimes who could not stop it, calling themselves "jihadist groups," an example of such is Hezbollah. Specifically, Hezbollah is a Lebanon-based violent organization made of radical Shi'a Muslims and driven by hatred against Israel and Western imperialism in the country. Part of the reason for the formation of this organization has been linked to U.S. interests in Iran during the Iranian revolution (Burc, 2014). The group blamed America for causing the troubles in the country, and Israel was viewed as an extension of the U.S. and a representative of its foreign interests in the region. Hezbollah was initiated in Iran and led by clerics and organizations who believed that the Iranian solution could help in the emancipation of Lebanon and its people. It supported and advocated for the use of terror to gain political objectives and free the people from an oppressive system (Blumenau, 2014). ISIS also joined the regional war, and that attracted the intervention of Western forces. Though Israel later withdrew from southern Lebanon, Hezbollah continued with its suicide bombing programs, ISIS targeted the West and amassed weapons with the help of some regional leaders. These violent groups have been connected with numerous terrorist attacks, an indication of its hatred towards the foreign interests in the region. The growth of Hezbollah and ISIS has been attributed to global politics and lack of a common approach. Most countries in the Middle East, including Iran, Iraq, Syria and Lebanon, have secretly funded the violent organizations to advance their political war against what they believe to be Western imperialism (Blumenau, 2014).

\subsection{Systemic Theory}

The theories-oriented on foreign policy consists of attempts to utilize insights from international relations theories (Gunter, 2015) to explain foreign policy decisions and its outcome. In light of space limitations, this part of the study focuses on neorealism, constructivism (Hopf, 1998) and liberalism. These are arguably the most prominent systemic international relations theories. These theories were primarily designed to explain general patterns of state interaction (Waltz 1996; Wendt 1999), but scholars have used, and argued for the use of, systemic theories to try to explain foreign policy in relations to violent non-state actors' and their activities (Baumann et al. , 1999; Jean, 2014; Josh, 2014, 2012; Houghton, 2007; Mearsheimer, 2001; Kahler, 2015, 2001; Wivel,2005). Although a rejection of systemic theories' utility for foreign policy studies seems premature, they do have significant problems with the inclusion of violent non-state actors. In this regard there are two problems that are relevant: state centrism and the unitary actor assumption. 
Neorealist foreign policy assumes that there is an anarchic structure of the international system where the states are central and that these states struggle for survival (Mearsheimer, 2001; Hinnebusch, 2014). Since for neorealists, states are the main actors and will remain so for the foreseeable time (Krieg, 2016; Hinnebusch, 2014), it basically declares non-state actors outside its area of responsibility. The neorealist assumption of "states as primary international actors" does not become seriously misleading or inadequate due to violent non-state actors. According to realists, IGOs are simply instruments of states. They cannot change the belief and behavior of states and the role of international institutions are marginal (Hinnebusch, 2014). However, some arguments of realists are proved to be inadequate and inefficient. Their main consideration that states as unitary actors have been strongly questioned by several perspectives such as bureaucratic politics, domestic politics, liberal, transnational, and regime models. Today, nation-states are no longer able to solve their problems only by themselves IOs are vehicles for states to push through their agendas (Mearsheimer, 1995), and transnational and private are of marginal importance compared to states. From a realist perspective, violent actors are only relevant in regard to their potential involvement in state behavior. Here a second problem comes into play, namely the unitary actor assumption. According to neorealism, the anarchic structure of the international system turns states into "like units" Hinnebusch, 2014), providing strong incentives for them to behave in a similar fashion.

Put differently, states behave like billiard balls on a pool table (Khashan, 2013), and understanding their actions does not require to open them up. That excludes potential VNSA involvement from the start. By allowing for at least some opening up of the black box of the state, postclassical realists are in a better position to account for VNSA, especially their involvement in states' foreign policies. Still, the question remains to what extent such an account would still be strictly realized (Marchetti, 2016). It is highly doubtful whether violent non-state actors could be integrated into a neorealist framework without giving up its bedrock assumptions. In this case, a neorealist does not provide the best starting point to examine violent non-state actors as a major problem in the Middle East. Constructivist accounts, at least in their Wendtian articulation, fare little better. Like Waltz, Wendt insists on the primacy of states and thus, like neorealist, declares itself not in charge of violet non-state actors. Similar to Waltz, Wendt conceptualizes the state as a unitary actor, not a disaggregated one that would allow for the analysis of the involvement of violent non-state actors in foreign policymaking. Indeed, insofar as at least Wendt has argued in favor of understanding states as persons, conventional constructivism even goes beyond neorealism in the commitment to the state as the only actor.

One exception in this regard is liberalism as formulated most prominently by Marchetti (2016) in the 1990s. According to liberalism, state action on the international level is mainly the result of the interplay of the different states' preferences. Importantly, states' preferences themselves are not the result of external system pressures but depend on the interests of the most influential societal actors. This in principle allows for an incorporation of violent non-state actors. The main channel through which the interests of societal actors translate into states' preferences are "representative institutions and practices" such as elections, which Moravcsik conceives of as a "transmission belt" (Marchetti, 2015 p.518). By understanding states primarily as transmission belts, liberalism allows for violent non-state actors to exert influence on decision-makers. Still, liberalism directs attention mainly to elections, not so much to dynamics within different organizations, decision-making bodies and so on that would allow us to examine precisely what it means for violent non-state actors getting involved independent of any democratic procedures.

\section{Foreign Interests in the Middle East}

There are many international actors that are competing for interests in the Middle East. The U.S., China and Russia form the major key players under discussion. The United States have a keen interest in ensuring a reliable and efficient flow of oil from the Middle East region to their country for use (Corbeil, 2016). While they mostly prefer lower oil prices, they understand that little can be done to control the price when it is market driven. However, they became concerned about supply disruptions and potential holdups by major producers. In order to deal with this concern, United States policymakers find it important and necessary to maintain military and political presence in the Persian Gulf area to ensure that trade routes remain open and the oil-rich countries there have "friendly" governments. They are keen to keep out potential rivals (e.g., Russians, who have historically tried to extend their influence in the region). In recent decades, such rivals have included Japan and particularly China within the region. These countries have tried to become powerful independently of the United States within the region (Mintz, \& DeRouen, 2010).

Another source of U.S. interests in the Middle East is the domestic security of Israel (Mishali-Ram, 2009). There are a number of powerful lobbies in the United States that identify with the interests of various groups in Israel. Though they have different views about Israel's interests, they have managed to ensure that American politicians accept a wide range of them as priorities. Some of these lobbies are led by Jewish groups who subscribe to Zionism 
for ethnic and ideological reasons (Mearsheimer \& Walt, 2006). The combination of efforts by these groups have become a powerful force in US politics that manifests itself in many different ways on a systematic basis, most notably in election processes. For example, during the presidential campaign, which brought in the government of President Donald Trump, Republican candidates did try to outdo each other in showing support for Israel to prove their credentials to conservative voters. This race led to a point where a candidate, Newt Gingrich by name, rejected the premise that Palestinians have a distinct identity that separates them from other Arabs and, thus, legitimizes their claim to constitute a nation.

He further claimed that the name Palestine had not been commonly used before the 1970s, although it is a wellknown fact that the land that came to be called Israel was part of a larger region that had been known as Palestine for centuries before 1948. No US politician who plans to remain in office dares to criticize Israeli actions and policies or the conduct of American policymakers who unconditionally support Israel and overlook its violations of international law and human rights. Even veteran politicians with pro-Israel credential who offer limited criticisms are treated harshly. For example, ex-President Carter was labeled as "anti-Semitic" and bombarded with personal attacks because of the views he expressed in his book, Carter (2006), even though those views were shared by many Israelis. Also, some academics who question America's lopsided policy towards Israel usually come under severe pressure. This was certainly the case for John Mearsheimer and Stephen Walt who wrote a well-known article on the matter arguing that unqualified US support for Israel is unnatural and unnecessary, in the sense that the costs of this support far outweigh the benefits for the United States (Mearsheimer \& Walt, 2006). Relentless critiques of their views came from many different quarters. It should be noted that the connection between the United States and Israel goes beyond the political sphere and has a non-negligible economic dimension as well. Israeli-American trade is significant for both countries. Moreover, given its scientific, business, and financial capabilities, Israel has become a source of technology and foreign investment for the U.S. (Mearsheimer \& Walt, 2006; Walt, 2010). The interests of Russia and China are similar to those of the U.S. However, these interests are much more focused on economic issues, with the non-oil components also having somewhat more weight. Their particular interests are in helping Middle East develop economically and politically while the U.S. is more focused on military presence in the Persian Gulf, where it is the dominant foreign power.

China gained increasing interest in Middle East as its economy has grown. On the one hand, Chinese economy has developed more thirst for energy. On the other hand, it has found Middle East markets lucrative outlets for its exports. To these ends, China has been trying to maintain good relations with all Middle East countries as well as the U.S. However, it has tried to cooperate with Iran more than other foreign powers for two reasons: First, the Islamic Republic offers some counterbalance to the U.S dominance in the region and gives China some bargaining power in its dealings with the West. Second, international sanctions and poor relations with the West put China in a good position to gain access to Iran's markets, with little competition from elsewhere (Seeberg, 2016b).

Russia's interests in Middle East have important differences as well as similarities with those of China. Russia is rich with energy resources and does not need to import oil from Middle East. Also, the range of products that it can export to the region is much more limited than is the case for China. So, economic concerns have limited weight in Russian interests in Middle East as a region. However, Russia has an interest in receiving cooperation from Middle Eastern countries, for maintaining security in its southern borders and exerting influence over former Soviet states. It also sees opportunities in Middle East, especially in the cases of Syria, for strengthening its bargaining position vis-à-vis the West (Hudson, 2015). Its strategy in this regard is to provide political and military support for these countries in a measured way, varying it according to its needs of its bargains with the U.S.

Given the interests of these key international actors in the Middle East region summarized above, the study will now proceed to analyze Hezbollah and ISIS with their various activities within the region.

\section{Hezbollah and Islamic State of Iraq and Syria}

Hezbollah is a significant violent non-state actor in the Middle East. It evolved from a Lebanese terrorist organization and grew into a powerful political and military group with a communication strategy. Not only has Hezbollah gained its importance at the national level, but it has also become a key player in the wider Middle East. Iran and Syria were believed to be the major sponsors of Hezbollah during its early years and they used the group in order to advance their objectives. As GonzálezÚbeda (2012) points out, despite Hezbollah's increasing autonomy and efforts to find alternative funding, Iran was the group's main financial provider. Syria does not just represent an important source of advanced weaponry; it is also the main transit point for the weapons that gets to Hezbollah (The Meir Amit Intelligence \& Terrorism Information Center, 2013b). Furthermore, Syria provided Hezbollah with a wide base of popular support, which gives the group a legitimacy that is vital for its survival. Given these interconnections, Hezbollah became an important force determining the dynamics of the crises that 
existed in the Middle East region especially the Syrian crisis. Hezbollah's determinations to fight against the foreign interests, as well as its solidarity, are two of the major drivers of Hezbollah's behavior and elements of utmost interest. In other words, Hezbollah is an important source of support for its interests and as an instrument that boosts its capacity to oppose foreign interests. Apart from Hezbollah's attacks throughout the Western world, all these factors make Hezbollah a violent actor anyone interested in international politics should understand. Hezbollah's influence in the Middle East conditions the policies and actions not only of Middle Eastern countries, but of the foreign interest that is being pursued, majorly by the United States, Russia and China in the region. The Islamic State of Iraq and Syria (ISIS) is a famous jihadist group which has been known under many names. In the West, it is most often referred to as either Islamic State of Iraq and the Levant (ISIL) or Islamic State of Iran and Syria (ISIS). The organization calls itself shortly as Islamic State (IS), while its regional enemies usually call it "Daesh", a derogatory term in Arabic (Winter, 2014). ISIS remains determined to challenge the Western interests in the Middle East. Its anti-American stance proclaimed has been emphasized in their various manifestos where ISIS reasoned that the resistance was necessary to counter the U.S. China and Russia's plans of domination of the Arab world "politically, economically, culturally, and through all aspects." Hassan Nasrallah referred to the armed resistance as a "national necessity" (Jain, 2017).

\subsection{Impact of Hezbollah and Isis on Foreign Interests}

The interference in the Middle East crisis by foreign interests led to the rise of Hezbollah and Islamic State of Iraq and Syria. In addition, the support of some groups by Russia, China and United States on the pretext of humanitarian intervention fuelled the Hezbollah and ISIS violent activities. As a result, ISIS denied Russia access to their oil pipeline route and that affected Russia's federal fund and foreign earnings, causing a decimation of profits for the Russian government. Furthermore, the trade route owned and managed by the Chinese construction company was destroyed by Hezbollah. This made China to lose trade route access from the Middle East to the rest of the world. In addition, the US military base in Syria was attacked by the ISIS and it resulted into casualties of some Americans.

\subsection{Conclusion}

The Middle East is a region that has divergent foreign interests and the activities of Hezbollah and ISIS was as a result of the interference of foreign countries vying for these divergent interests in the Middle East. The role of Hezbollah and ISIS as identified by the study showed that violent non-state actors have influence on the policies and actions of governments across the Middle East. The study concluded that the foreign economic and military interests in the Middle East had been decimated by Hezbollah and ISIS. The study recommended that the various governments of the Middle East in dealing with the foreign interests should take cognizance of the internal demands of their citizens.

\section{References}

Aydinli, E. (2013). "Assessing Violent Non-state Actorness in Global Politics: A Framework for Analysis." Cambridge Review of International Affairs, 121doi:10.1080/09557571.2013.819316.

Baumann, R., \& Stengel. F. (2013). "Foreign Policy Analysis, Globalization and NonState Actors: State-Centric after All?" Journal of International Relations and Development Volume 17 (4): 489-521. doi:10.1057/jird.2013.12.

Benson, M., Kugler, J. (2016). Power Parity, Democracy, and the Severity of Internal Violence, The Journal of Conflict Resolution

Blumenau, B. (2014). "The Other Battleground of the Cold War: The UN and the Struggle against International Terrorism in the 1970s.” Journal of Cold War Studies 16, no. 1 (April): 61-84.

Brown, S. (2016). "Purposes and Pitfalls of War by Proxy: A Systemic Analysis." Small Wars \& Insurgencies Volume 27 (2): 243-57. doi:10.1080/09592318.2015.1134047.

Burç, A. ( 2014). "Paradigm Change in Turkish Foreign Policy after Post-Cold War." Alternatives: Turkish Journal of International Relations 13, no. 3: 55-73.

Bush, S. (2016). When and why is civil society support "made-in-America"? Delegation 
to non-state actors in American democracy promotion. The Review of International Organizations, Volume 11(3), 361-385.

Carter, J. (2006). Palestine: Peace Not Apartheid. New York, NY, Simon and Schuster, Inc.

Corbeil, A. (2016). “Hezbollah Is Learning Russian.” Washington D.C. http://carnegieendowment.org/sada/62896. Retrieved 15/09/2017

Demollari, E. (2015). "Germany and its Influential Role in the Iraq Issue. Start of Cracks in Relations between Germany and the US?” Revista De Stiinte Politice, no. 47 (March): 236-44.

González-Úbeda Alférez, M. (2012). Hezbollah, Hamás y la Primavera Árabe. Madrid: Instituto Español de Estudios Estratégicos.

Gunter, M. (2015). Iraq, Syria, Isis and the Kurds: Geostrategic Concerns for the U.S. and Turkey. Middle East Policy; 22 (1): 102-111.

Hinnebusch, R. (2014). “Foreign Policy in the Middle East.” In The Foreign Policies of Middle East States, 1-34. Doi: 10.1017/s002074380639126x.

Hudson, M. (2015). Arab Politics, the Search for Legitimacy, Yale

Jain, A. (2017). U.S. policy on Hizballah: the question of engagement. PolicyWatch 1679. Retrieved September 22, 2018, from The Washington Institute: http://www.washingtoninstitute.org/policy-analysis/view/u.s.- $\quad$ policy-on-hizballah-the-question-ofengagement

Jean, A. (2014). Islamic extremism on Rise in Jordan, Al-Monitor, May 18, 2014, www.almonitor.com/pulse/originals/2014/05/jordan-fears-syria-war-islamists.html.Retrieved 15/10/2017

Josh, L. (2014). 19 die as violent protests over ISIS sweeps Turkey, CNN, October 9, 2014, www.//edition.cnn.com/2014/10/08/world/meast/turkey-isis-protests/.Retrieved 23/09/2016

Kahler, M. (Ed.) (2015). Networked Politics: Agency, Power, And Governance. Ithaca, NY and London: Cornell University Press.

Khashan, H. (2013). The political isolation of Lebanese Sunnis. Middle East Quarterly, 20 (3), 69-75.

Krieg, A. (2016). Externalizing the burden of war: the Obama Doctrine and US foreign policy in the Middle East. International Affairs, 92(1), 97-113.

Marchetti, R. (2016). Global Strategic Engagement: States and Non-State Actors in Global Governance. Lanham et al.: Lexington Books.

Mearsheimer, F., \& Stephen M. (2006). "The Israel Lobby and U.S. Foreign Policy”. Middle East Policy, 13.3: 29-87.

Meier, D. (2015). Popular mobilizations in Lebanon: From anti-system to sectarian claims. Democracy and Security; 11 (2): 176-189.

Mintz, A, \& DeRouen K. (2010). Understanding Foreign Policy Decision Making. Cambridge: Cambridge University Press. doi:10.1017/CBO9781107415324.004.

Mishali-Ram, M. (2009). "Powerful Actors Make a Difference: Theorizing Power Attributes of Non-state Actors.” International Journal of Peace Studies 14 (2): 55-82.

Naím, M. (2014). The End of Power: From Boardrooms to Battlefields and Churches to States, Why Being In Charge Isn't What It Used to Be. New York: Basic Books. 
Poole, H. (2004). Tactics of the Crescent Moon, Militant Muslim Combat Methods, Posterity Press

Reuter, C. (2015). "The Terror Strategist: Secret Files Reveal the Structure of Islamic

State." Der Spiegel, April 18. http://www.spiegel.de/international/world/islamic-state-filesshow-structure-of-islamist-terror-group-a-1029274.htm. Retrieved on 14/12/2016

Seeberg, P. (2016a). The Crisis in Syria, international and regional sanctions, and the transformation of the political order in the levant. In: Beck M, Jung D and Seeberg P (eds). The Levant in Turmoil. Syria, Palestine, and the Transformation of Middle Eastern Politics. Palgrave Macmillan: New York, pp 101-122.

The Meir Amit Intelligence and Terrorism Information Center. (2013b). Hezbollah involvement in the Syrian civil war. Retrieved September 19, 2018, from The Meir Amit Intelligence and Terrorism Information http://www.terrorisminfo.org.il/Data/articles/Art_20521/E_062_13 827044787.pdf

Center: 